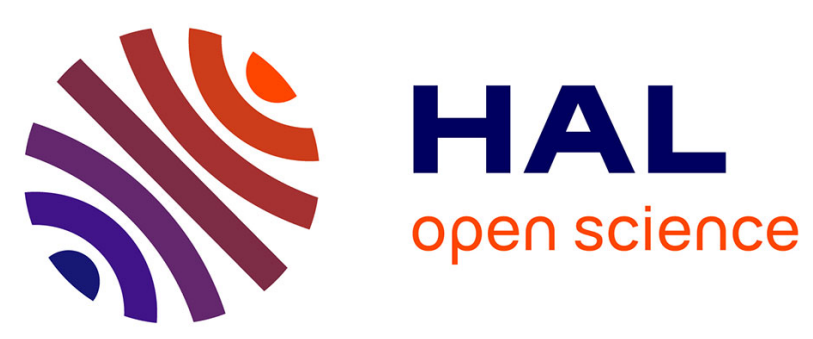

\title{
The in vitro mechanisms of isoniazid and ethionamide resistance poorly reflect those in vivo in Mycobacterium tuberculosis
}

Florence Brossier, Emmanuelle Cambau, Emilie Tessier, Vincent Jarlier, Wladimir Sougakoff

\section{To cite this version:}

Florence Brossier, Emmanuelle Cambau, Emilie Tessier, Vincent Jarlier, Wladimir Sougakoff. The in vitro mechanisms of isoniazid and ethionamide resistance poorly reflect those in vivo in Mycobacterium tuberculosis. Tuberculosis, 2016, 101, pp.144 - 145. 10.1016/j.tube.2016.09.028 . hal01402952

\section{HAL Id: hal-01402952 https://hal.sorbonne-universite.fr/hal-01402952}

Submitted on 25 Nov 2016

HAL is a multi-disciplinary open access archive for the deposit and dissemination of scientific research documents, whether they are published or not. The documents may come from teaching and research institutions in France or abroad, or from public or private research centers.
L'archive ouverte pluridisciplinaire HAL, est destinée au dépôt et à la diffusion de documents scientifiques de niveau recherche, publiés ou non, émanant des établissements d'enseignement et de recherche français ou étrangers, des laboratoires publics ou privés. 
3 The in vitro mechanisms of isoniazid and ethionamide resistance poorly reflect those in

4 vivo in Mycobacterium tuberculosis

5

6 Florence BROSSIER ${ }^{\mathrm{a}, \mathrm{b}, \mathrm{c}, *}$, Emmanuelle CAMBAU $^{\mathrm{a}, \mathrm{d}, \mathrm{e}}$, Emilie TESSIER ${ }^{\mathrm{a}}$, Vincent

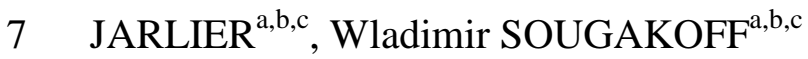

8

9 a National Reference Center for Mycobacteria and Antimycobacterial Resistance, Paris, France.

${ }^{\mathrm{b}}$ AP-HP, Hôpital Pitié-Salpêtrière, Laboratory of Bacteriology, Paris, France.

$11{ }^{c}$ Sorbonne Universités, UPMC Univ Paris 06, INSERM, UMRS1135, CIMI-Paris, team 13, 12 Paris, France.

13 d AP-HP, Hôpital Lariboisière, Laboratory of Bacteriology, Paris, France.

$14{ }^{\mathrm{e}}$ Univ Paris Diderot, IAME UMR1137, Sorbonne Paris Cité, Paris, France.

* Correspondence to Florence Brossier, Laboratoire de Bactériologie-Hygiène, Faculté de 18 Médecine, Pitié-Salpêtrière, 91 boulevard de l'Hôpital, F-75634 Paris Cedex 13, France. 
To be active against Mycobacterium tuberculosis, isoniazid (INH) and ethionamide (ETH) need to be activated by the catalase/peroxidase KatG for INH and by the mono-oxygenase EthA (regulated by EthR) for ETH [1]. ETH and INH both target the enzyme InhA involved in the cell wall biosynthesis [2]. Clinical isolates resistant (R) to INH and ETH display a wide range of mutations altering KatG (mutation S315T in $70 \%$ of INH-R isolates), EthA (in 50\% of ETH-R isolates) and, InhA and the inhA promoter (in $25 \%$ of INH-R and $65 \%$ of ETH-R isolates) $[1,3]$.

Here we selected INH-R and ETH-R in vitro mutants in order to investigate, in an isogenic context, the effects of the mutations observed in clinical isolates. Mutants were selected on Middlebrook 7H11 agar containing INH or ETH. The genes ethA, ethR, katG, inhA and the inhA promoter were sequenced for $115 \mathrm{M}$. tuberculosis in vitro mutants as previously described [3].

The mutants selected on INH displayed alterations in katG only (46/69), with the following mutations: missense (12/69), nonsense (14/69), insertion (2/69), partial and complete deletion of $k a t G$ (13/69 and 5/69, respectively) (Table 1). The mutants selected on ETH showed alteration in ethA (11/46) and the ethA-ethR intergenic region (1/46), with the following mutations in ethA: missense (5/46), nonsense (4/46) and deletion (2/46) (Table 1).

The distribution of the mutations selected in vitro does not reflect the mechanisms of INHand ETH-R usually observed in clinical isolates. The most common mutations found in the INH-R clinical isolates (KatG S315T and inhA promoter c-15t) were not found in our in vitro INH-R mutants which, by contrast, preferentially showed deletions in katG (46\%), a genotype that is rarely observed in clinical isolates [1]. This observation is consistent with Bergval et al for INH [4]. However, we observed more missense mutations (12/69 vs 2/120) and the mutations we obtained were selected with the lowest concentrations of INH $(0.2$ and 0.4 


\section{.}

$\mathrm{mg} / \mathrm{l}$ ), compared to Bergval et al [4] who performed the selection of resistant mutants at concentrations of $0.4,1.0$ and $20 \mathrm{mg} / \mathrm{l}$.

KatG allows bacteria to resist killing by the phagocyte oxidative burst happening when $M$. tuberculosis are in contact with the host's immune system $[1,5]$. The mutation KatG S315T predominantly found in clinical INH-R strains represents the best compromise between the conservation of catalase-peroxidase activities and a drastic reduction in the INH activation [1]. The high rate of deletion in KatG observed in in vitro mutants, which are resistant to isoniazid but susceptible to oxidative burst, could be favored by the in vitro culture conditions where there is no significant oxidative stress.

Similarly, the c-15t mutation in the inhA promoter, commonly found in clinical isolates coresistant to INH and ETH, was not observed in our ETH-R mutants which displayed mutations only in EthA and the ethA-ethR intergenic region. Finally, for $33 \%$ and $74 \%$ of the INH-R and ETH-R mutants obtained in vitro, respectively, no mutation was found in ethA, ethR, katG, inhA and the inhA promoter.

\section{ACKNOWLEDGMENTS}

This work was supported by an annual grant from the Institute National de la Santé et de la Recherche Médicale (INSERM) and the Université Pierre et Marie Curie (UPMC). (1) 


\section{REFERENCES}

73 [1] Vilchèze C, Jacobs WR Jr. Resistance to isoniazid and ethionamide in Mycobacterium 74 tuberculosis: genes, mutations, and causalities. Microbiol Spectr 2014;2:MGM2-0014752013

76 [2] Banerjee A, Dubnau E, Quemard A, Balasubramanian V, Um KS, Wilson T, Collins D, de 77 Lisle G, Jacobs WR Jr. inhA, a gene encoding a target for isoniazid and ethionamide in $78 \quad$ Mycobacterium tuberculosis. Science 1994;263:227-230.

[3] Brossier F, Veziris N, Truffot-Pernot C, Jarlier V, Sougakoff W. Molecular investigation of resistance to the antituberculous drug ethionamide in multidrug-resistant clinical isolates of Mycobacterium tuberculosis. Antimicrob Agents Chemother 2011;55:355-360.

[4] Bergval IL, Schuitema AR, Klatser PR, Anthony RM. Resistant mutants of Mycobacterium tuberculosis selected in vitro do not reflect the in vivo mechanism of isoniazid resistance. J Antimicrob Chemother 2009;64:515-523.

[5] Manca C, Paul S, Barry CE $3^{\text {rd }}$, Freedman VH, Kaplan G. Mycobacterium tuberculosis catalase and peroxidase activities and resistance to oxidative killing in human monocytes in vitro. Infect Immun 1999;67:74-79. 

vitro by isoniazid or by ethionamide

\begin{tabular}{|c|c|c|c|}
\hline $\begin{array}{l}\text { Resistance } \\
\text { phenotype } \\
\text { (no. of isolates) }\end{array}$ & Gene & $\begin{array}{l}\text { Type of } \\
\text { mutations } \\
\text { (no. of isolates) }\end{array}$ & $\begin{array}{l}\text { Mutation }{ }^{\mathrm{a}} \\
\text { (no. of isolates indicated if different of } 1 \text { ) }\end{array}$ \\
\hline \multirow[t]{7}{*}{$\begin{array}{l}\text { Isoniazid } \\
(\mathrm{n}=69)\end{array}$} & \multirow[t]{6}{*}{ katG } & missense $(n=12)$ & 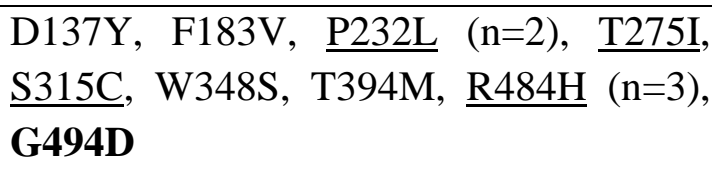 \\
\hline & & nonsense $(n=14)$ & $\begin{array}{l}\text { Q50*, } \\
\frac{\mathrm{W} 91^{*}}{\mathrm{~W} 328^{*}}(\mathrm{n}=2), \mathrm{W} 135^{*}, \\
\mathrm{Y}=2), \mathrm{K} 152^{*},\end{array}$ \\
\hline & & insertion $(n=2)$ & ins g 1110 , ins a 1604 \\
\hline & & $\begin{array}{l}\text { deletion }(n=18) \\
{ }^{\circ} \text { partial }(n=13)\end{array}$ & $\begin{array}{l}\text { del c } 351 \text {, del g } 367 \text {, del aagaac } 469-475 \text {, } \\
\text { del t } 548 \text {, del catc } 1391-1394(n=8) \text {, del a } \\
1668\end{array}$ \\
\hline & & ${ }^{\circ}$ total $(\mathrm{n}=5)$ & \\
\hline & & $\begin{array}{l}\text { wild-type } \\
(\mathrm{n}=23)\end{array}$ & \\
\hline & inhA or its promoter & $\begin{array}{l}\text { wild-type } \\
(\mathrm{n}=69)\end{array}$ & \\
\hline \multirow{8}{*}{$\begin{array}{l}\text { Ethionamide } \\
(\mathrm{n}=46)\end{array}$} & \multirow[t]{4}{*}{ ethA } & missense $(n=5)$ & T44N, G52E, A252D, A341V (n=2) \\
\hline & & nonsense $(n=4)$ & Q360* $(n=2), W 456 *(n=2)$ \\
\hline & & deletion $(n=2)$ & del g 88 , del a 256 \\
\hline & & $\begin{array}{l}\text { wild-type } \\
(\mathrm{n}=35)\end{array}$ & \\
\hline & \multirow[t]{2}{*}{ ethA-ethR intergenic } & $\begin{array}{l}\text { single } \quad \text { base } \\
(\mathrm{n}=1)\end{array}$ & $\mathrm{a}-68 \mathrm{~g}$ \\
\hline & & $\begin{array}{l}\text { wild-type } \\
(\mathrm{n}=45)\end{array}$ & \\
\hline & ethR & $\begin{array}{l}\text { wild-type } \\
(\mathrm{n}=46)\end{array}$ & \\
\hline & inhA or its promoter & $\begin{array}{l}\text { wild-type } \\
(\mathrm{n}=46)\end{array}$ & \\
\hline
\end{tabular}

$90{ }^{\mathrm{a}}$ The mutated codons previously reported in the literature in clinical strains are indicated in

91 bold when the corresponding amino acid is conserved, or are underlined when the encoded

92 amino acid is modified compared to our study [1]. 